\title{
Benthic Community Zonation in a Breakwater on the North Coast of the State of Rio de Janeiro, Brazil
}

\author{
Bruno Pereira Masi, Isabela Maria Macedo and Ilana Rosental Zalmon* \\ Centro de Biociências e Biotecnologia; Universidade Estadual do Norte Fluminense; Av. Alberto Lamego, 2000; \\ 28013-602; Campos dos Goytacazes - RJ - Brasil
}

\begin{abstract}
The present study presents the vertical zonation pattern of the intertidal benthic organisms on granitic boulders in the Farol de São Tomé beach $\left(22^{\circ} 02^{\prime} S, 41^{\circ} 03^{\prime} W\right)$, Rio de Janeiro State. Four sampling profiles using $20 x 20 \mathrm{~cm}$ quadrats through a photo quadrat technique revealed four horizontal bands: (1) Littoral Fringe characterized by empty space and Littorina; (2) Upper eulittoral mainly occupied by Chthamalus and bare rock; (3) Lower eulittoral characterized by Chthamalus, Phragmatopoma, Ulva and Centroceras; and (4) Sublittoral Fringe characterized by Ulva, Phragmatopoma and Hypnea. The high variability in the relative abundance of the dominant species among the profiles may be attributed to the high topographic irregularity, reflecting in different wave action intensity at the same height, and consequently favoring the establishment of different species. The frequent substrate alternation from granitic rock to Phragmatopoma sandy reefs might contribute to the small-scale spatial variability. The implantation of a breakwater on an area without natural rocky shores allowed the study of intertidal benthic communty zonation, and provide a baseline for the experimental studies.
\end{abstract}

Key words: Intertidal zonation, rocky shore, benthic community, north coast of Rio de Janeiro

\section{INTRODUCTION}

Intertidal rocky shores present several organisms, which are commonly distributed in specific zones or particular associations parallel to the coast, with floral and faunal variations over short horizontal distances. The vertical distribution of these bands is related mainly to a gradient of emersion/desiccation and also to others physical and biological factors, including wave exposure (Lewis, 1964, Underwood, 1981; Araújo et al., 2005), tidal dynamics (Denny and Paine, 1998), temperature (Tomanek and Helmuth, 2002), salinity (Zacharias et al., 2001), substrate orientation (Chapman and Bulleri, 2003), topography heterogeneity (Archambault and Bourget, 1996; Cusson and Bourget, 1997; Guichard and Borget, 1998; Guichard et al., 2001), predation and competition (Connell, 1961), disturbance and succession (Souza, 1979), grazing (Apolinário et al., 1999, Bulleri et al., 2000) and recruitment (Forde and Raimondi, 2004; Skinner and Coutinho, 2005). Their relative importance is hard to generalize, due to the frequently high number of potential factors involved and, mainly, due to their interactions (Little and Kitching, 1996).

Benthic community zonation patterns are well known (Stephenson and Stephenson, 1949; LEWIS, 1964), and this subject has been discussed by

\footnotetext{
* Author for correspondence: ilana@uenf.br
} 
several authors (Underwood, 1981; Oliveira and Paula, 1984; Thomas, 1985; Coutinho, 1995, 2002; Benedetti-Cecchi and Cinelli, 1997; Brattstrom, 1999; Boaventura, 2002; Good, 2004). For marine biologists, the zones are extremely useful in a practical sense because they provide a convenient descriptive framework into which specific observations can be fitted (Little and Kitching, 1996).

On rocky shores, substrate topography may have a spatial influence on the intensity of environmental variables, which in turn, might affect the biological processes during both low and high tide periods (Guichard et al., 2001). The physical features of the environment, and consequently the structure of the local assemblage may change abruptly over a very small spatial scale in high complexity habitats (Benedetti-Cecchi and Cinelli, 1997).

Antropogenic coastal alterations (i.e. installation of structures in coastal areas) modify the landscape by adding new habitats and favoring benthic community recruitment or colonization. Several studies on benthic organisms' distribution have been carried out in artificial environments such as seawalls and breakwaters (Chapman and Bulleri, 2003; Bulleri and Chapman, 2004; Bulleri, 2005). The latter, made of transplanted boulders are discontinuous and irregular and are characterized by a high surface complexity.

The objective of the present study was to characterize the vertical zonation of benthic organisms in the intertidal zone on a breakwater of transplanted granitic boulders 20 years after the implantation of a rocky substrate on the north coast of the State of Rio de Janeiro. The breakwater was implanted at the beginning of a fishing harbor that started in 1980 but was interrupted. Since the qualitative and quantitative data about the vertical distribution of benthic organisms' patterns in this region are inexistent, this study provides an observational basis for future experimental studies.

The characterization of rocky shore communities through distribution and abundance data is the first step to understand the benthic dynamics and is usually the only framework for ecological and management decisions (Sabino and Villaça, 1999).

\section{MATERIALS AND METHODS}

\section{Study area}

The study was done on the Farol de São Tomé beach $\left(22^{\circ} 02^{\prime} \mathrm{S}, 41^{\circ} 03^{\prime} \mathrm{W}\right)$, located on the Cape of São Tomé along the northern coast of the State of Rio de Janeiro (Fig. 1). The environment has a set of granitic boulders presenting a discontinuous and irregular surface forming "steps" (Fig. 1). The rocky substrate is located $10 \mathrm{~m}$ distant from the beach and is approximately $30 \mathrm{~m}$ in length. The northeast wind is predominant in the region throughout the year. The sampling program was carried out on the southern face of the Pier, where wave action is less intense.
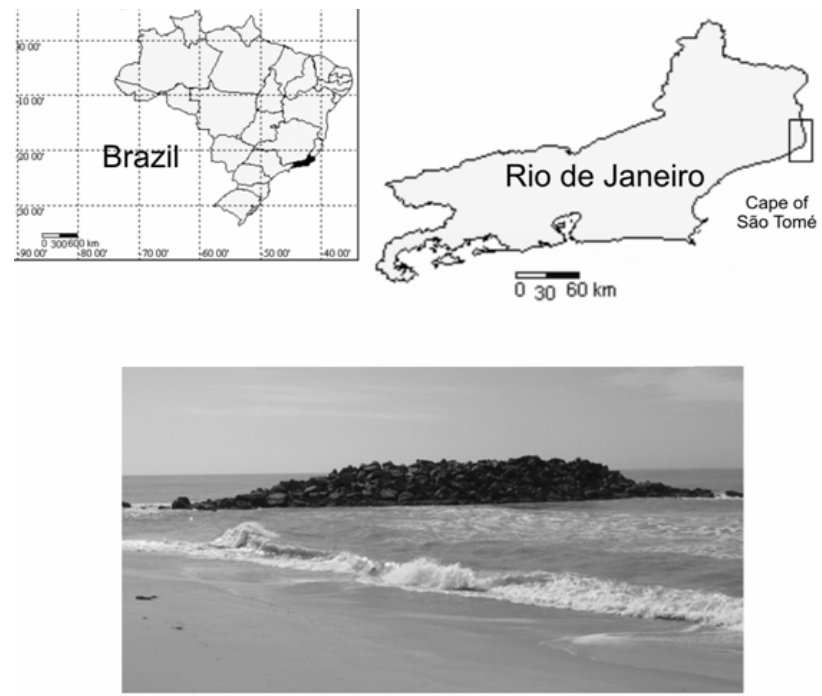

Figure 1 - Localization of the study area at the northern coast of Rio de Janeiro State and the breakwater on Farol de São Tomé beach. 
The sampling program was carried out in May 2005. The organisms were collected previously for identification of the community composition. The cirripeds Chthamalus proteus Dando and Southward, 1980 and C. bisinuatus Pilsbry, 1916 were characterized only at the genus level since it was impossible to distinguish them in situ.

Four vertical profiles, 4 meters wide, represented each one a study unit. Along each profile, 10 levels were photographed from 0.2 meters above tide level to a selected point above the marine organism on the highest portion of the rocky substrate (generally Littorina sp). Due to substrate discontinuity, the determination of each observation height was performed by sections using the adapted Gevertz method (1995). The random sampling surface at each section had its external faces relatively perpendicular and also facing to the sea. A digital camera Cannon PowerShot A510 3.2 Mp in a watertight compartment was attached to a $20 \times 20 \mathrm{~cm}$ polyvinyl chloride (PVC) photoquadrat framer (Preskitt et al., 2004). Each photo was analyzed for percent cover using the CPCe V 3.1 (Coral Point Count with Excel extensions) software program, which estimate bare space and the species percentage cover applied to a grid of 100 points in the digital photography (Kohler and Gill, 2006). The distinction between primary and secondary canopy was not considered.

The tide levels were calculated using the tides' table for the Imbetiba Marine Terminal (http://www.mar.mil.br/dhn/chm/tabuas/index.htm).

The benthic assemblages at the different levels were evaluated through taxonomic composition; species richness (average number); Brillouin's diversity (Zar, 1984) and species average percentage cover in each profile.

The comparative analysis of the benthic assemblages at different heights included a cluster analysis (UPGMA) and a Multi Dimensional Scaling (MDS) both with Bray-Curtis Similarity coefficient for percentage data. Cluster reliability to data was evaluated by the cophenetic coefficient.

Similarity Percentages Procedure (SIMPER) defined the percentual contribution of the most abundant species between and within the groups of the cluster analysis (Clarke and Warwick, 2001).
A cut-off of cumulative dissimilarity of $80 \%$ was applied (Boaventura et al., 2002).

Data analysis was performed with PRIMER software (Clarke and Warwick, 2001) and the cophenetic coefficient was calculated with NSTSYSpc 2.1 software.

A graphical representation of the vertical distribution pattern was elaborated in a diagram where the tide levels were also indicated. The intertidal nomenclature of the different horizontal levels was based on Lewis' (1964) zonation scheme and terminology, calling the top zone as "littoral fringe", the middle zone as "eulittoral zone" and the top zone as "sub-littoral fringe".

\section{RESULTS}

A total of 13 marine invertebrates and algae taxa were found: the chlorophytes Chaetomorpha sp Kuetzing 1845 and Ulva fasciata Delile 1813; the rhodophytes Centroceras clavulatum (C. Agardh) Montagne, Gymnogongrus griffithsiae (Turner) Martius and Hypnea musciformis (Wulfen) Lamouroux; the cirripeds Chthamalus spp and Tetraclita stalactifera (Lamarck, 1818); the gastropods Collisella subrugosa (Orbigny, 1846), Littorina ziczac (Gmelin, 1791) and Stramonita haemastoma (Linnaeus, 1758); the bivalves Brachidontes solisianus and Perna perna (Linnaeus, 1758) and the polychaete Phragmatopoma lapidosa Kinberg (1867).

The vertical distribution of the representative organisms is shown on Figure 2. The uppermost quadrats (Q10 and Q09: 2.2 to $1.8 \mathrm{~m})$ were characterized by bare rock and Littorina ziczac. Chthamalus spp and B. solisianus were the main species in the quadrats Q08, Q07, Q06 and Q05 (1.8 to $1.0 \mathrm{~m})$. The lower quadrats $(\mathrm{Q} 04, \mathrm{Q} 03$ and Q02: 1.0 to $0.4 \mathrm{~m}$ ) were dominated by $C$. clavulatum, P. perna, P. lapidosa and U. fasciata. The last species and $H$. musciformis were the most representative of the lowermost level (Q01: 0.4 to $0.2 \mathrm{~m})$.

The average species diversity and richness were higher in the intermediate quadrat $(\mathrm{Q} 05: \mathrm{H}=1.25$, $\mathrm{N}=7.8$ ). The lowest values were recorded in the uppermost quadrat $(\mathrm{H}=0.07, \mathrm{~N}=2)$ (Fig. 3). 

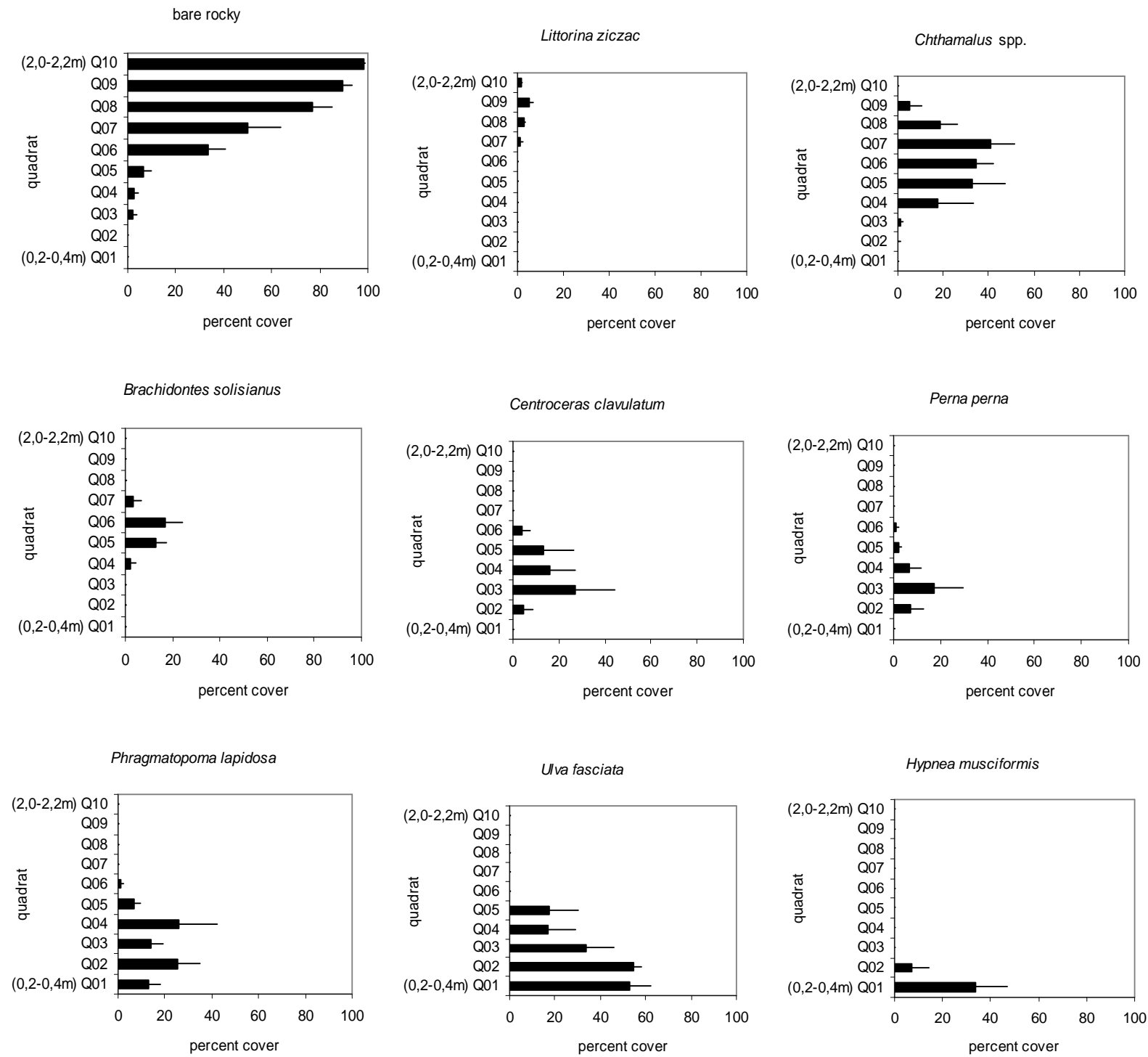

Figure 2 - Percent cover average values $( \pm$ SE; $N=4$ sample units) of the most abundant organisms (contributing with $>5 \%$ percent cover) along the intertidal zone on the north coast of Rio de Janeiro.

The cluster analysis of the sampled heights showed four main groups with $52 \%$ of similarity (Fig. 4), Group I with the upper quadrat (Q10 to Q08: 2.2 to $1.6 \mathrm{~m}$ ), Group II with the intermediate upper quadrat (Q07 and Q06: 1.6 to $1.2 \mathrm{~m}$ ), Group III with the intermediate lower quadrat (Q05 and Q04: 1.2 to $0.8 \mathrm{~m}$ ) and Group IV included the inferior quadrat (Q03 to Q01: 0.8 to $0.2 \mathrm{~m}$ ). The cophenetic coefficient value $(r=0.88)$ was higher than the acceptable $(r=0.80)$, reflecting the cluster reliability. The resulting MDS (Fig. 4) showed a progressive ordination displaying of the benthic assemblages across the set of sampled heights, which reflected a vertical continuum. The stress value of 0.01 for the 2-dimensional MDS configuration was low, indicating an excellent graphic representation. 

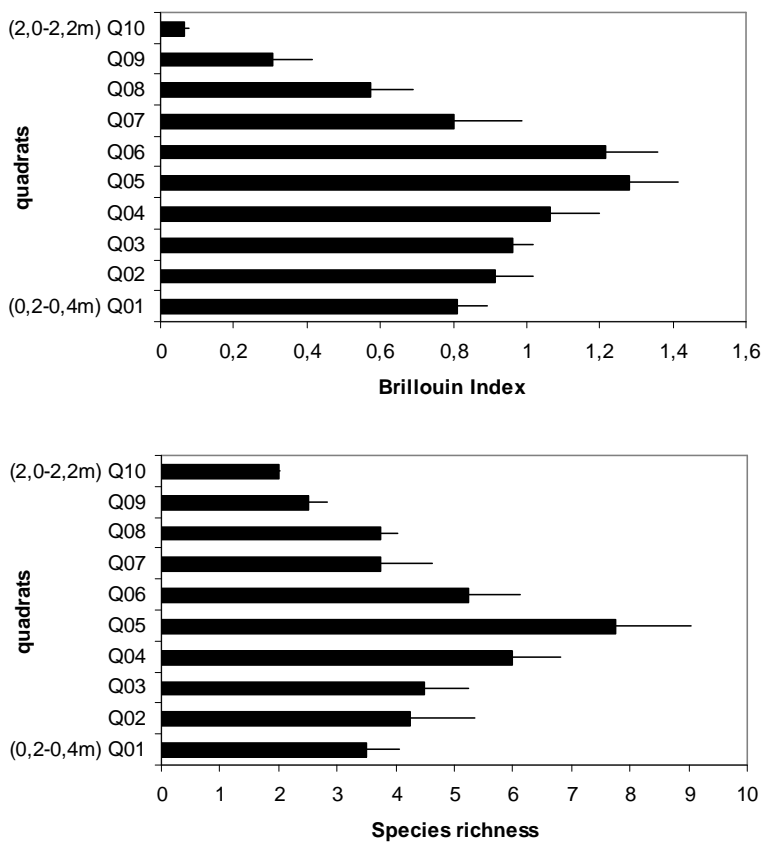

Figure 3 - Brillouin's diversity and species richness average values $( \pm \mathrm{SE} ; \mathrm{N}=4$ sample units) along the intertidal zone on the north coast of Rio de Janeiro.

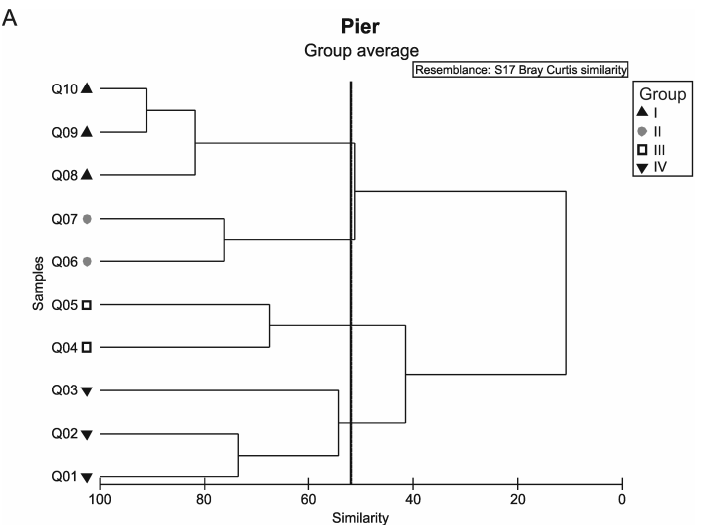

B

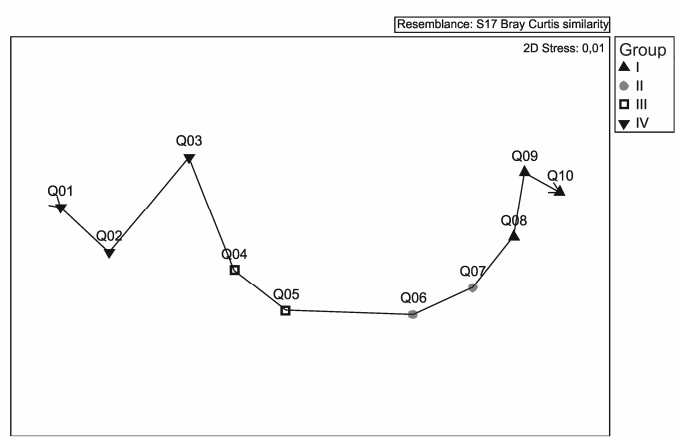

Figure 4 - A. Cluster analysis (cophenetic coefficient value $=0.88$ ) and B. MDS ordination plot (stress value $=0.01$ ) with Bray-Curtis Similarity coefficient of species percent cover with group average linking of the benthic assemblages at different heights along the intertidal zone on the north coast of Rio de Janeiro (Q01 - lowermost quadrat: 0.2 to $0.4 \mathrm{~m}$; Q10 - uppermost quadrat: 2.0 to $2.2 \mathrm{~m}$ ). 
The SIMPER analysis defined the percent contribution of the most abundant species between the groups of the cluster analysis (Table 1a). Bare rock was the most common feature for Group I (95.58\%) and also for Group II, together with Chthamalus spp (89.83\%). For Group III, Chthamalus spp., U. fasciata, C. clavulatum and $P$. lapidosa were the most common species $(81.84 \%)$, while $U$. fasciata and $P$. lapidosa contributed to the highest similarity to Group IV $(88.32 \%)$.

The average dissimilarities between each pairwise combination of neighbor groups revealed by SIMPER analysis (Table 1b) showed that Groups I and II differed in $88.26 \%$ due to bare rock, Chthamalus spp and B. solisianus. Besides bare rock, several species were responsible for the dissimilarity between Groups II and III (80.63\%): Chthamalus spp, U. fasciata, P. lapidosa and $C$. clavulatum, respectively. The analysis showed that Groups III and IV differed (83.45\%) mainly by the species $U$. fasciata, Chthamalus spp, $H$. musciformis, C. clavulatum and P. lapidosa, respectively.

Tabela 1 - SIMPER analysis with the contributing species to the similarity within groups (Ia) and between groups (Ib) of the cluster analysis.

\begin{tabular}{|c|c|c|c|c|c|}
\hline Ia & Similarity within groups (\%) & I & II & III & IV \\
\hline & Bare rock & 95.58 & 44.26 & & \\
\hline & Chthamalus spp & & 45.57 & 25.93 & \\
\hline & Centroceras clavulatum & & & 20.00 & \\
\hline & Ulva fasciata & & & 25.19 & 66.48 \\
\hline & Phragmatopoma lapidosa & & & 10.37 & 21.84 \\
\hline & Total & 95.8 & 89.83 & 81.84 & 88.32 \\
\hline \multirow[t]{9}{*}{$\mathrm{Ib}$} & Dissimilarity between groups (\%) & & I vs II & II vs III & III vs IV \\
\hline & Bare rock & & 47.48 & 31.47 & \\
\hline & Chthamalus spp & & 30.49 & 10.63 & 20.98 \\
\hline & Brachidontes solisianus & & 10.29 & & 6.52 \\
\hline & Ulva fasciata & & & 14.42 & 25.68 \\
\hline & Phragmatopoma lapidosa & & & 13.37 & 8.01 \\
\hline & Centroceras clavulatum & & & 10.74 & 10.65 \\
\hline & Hypnea musciformis & & & & 11.61 \\
\hline & Total & & 88.26 & 80.63 & 83.45 \\
\hline
\end{tabular}

The graphic representation of the vertical distribution pattern of the benthic assemblages on the studied breakwater is shown in Figure 5. The position of these assemblages was related to a conventional level called "chart datum" (CD) and the tide levels for the period of 30 days before the sampling date is indicated. The different zonation scheme was based on Lewis (1964) with four bands: the highest zone dominated by small snails
(Littorina ziczac), called "littoral fringe" (2.2 to $1.6 \mathrm{~m})$, the upper mid-shore zone characterized by invertebrates, named "upper eulittoral zone" (1.6 to $1.2 \mathrm{~m}$ ), the lower mid-shore represented by several invertebrates and algae, called "lower eulittoral zone" (1.2 to $0.8 \mathrm{~m})$ and at the lowest band, an algal bed zone called "sub-littoral fringe" (0.8 to $0.2 \mathrm{~m})$. 


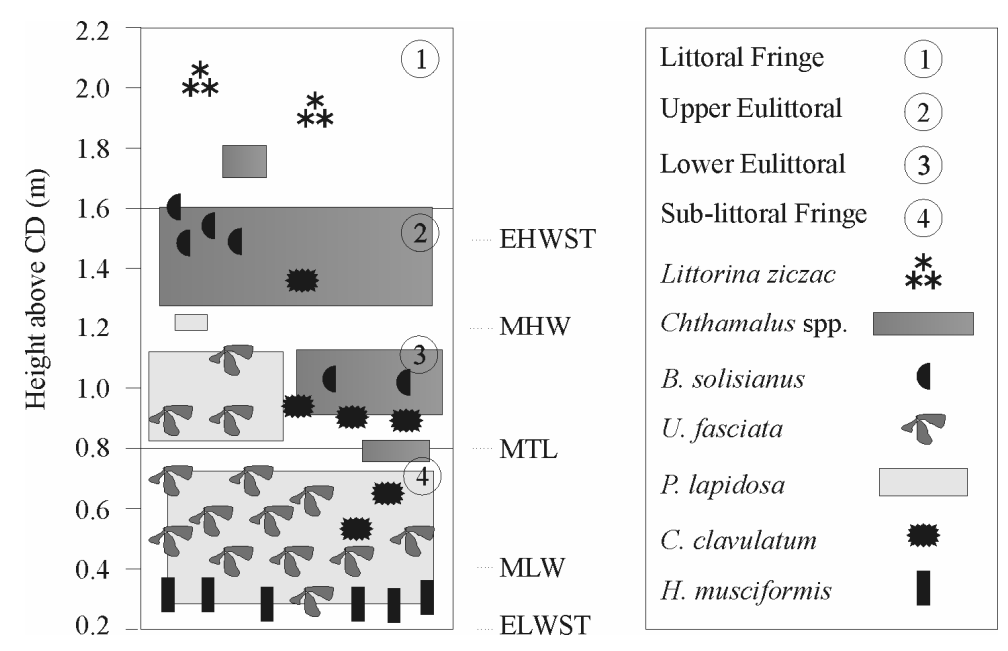

Figure 5 - Schematic zonation diagram of the benthic intertidal assemblages on the studied breakwater on north coast of Rio de Janeiro and the height above "chart datum" (CD). EHWST - extreme high-water of spring tide, MHW - mean high-water, MTL mean tide level, MLW - mean low-water, ELWST - extreme low-water of spring tide.

\section{DISCUSSION}

The qualitative and quantitative results suggest a banding pattern for the benthic organisms in the studied intertidal zone, with four major zones: Littoral Fringe, Upper Eulittoral Zone, Lower Eulittoral Zone and Sub-littoral Fringe.

The superior band of the substrate called Littoral Fringe (2.2-1.6m) was above the highest tide level (EHWST: extreme high water spring tide), where humidity came from the salt water spray generated by wave action and explained the bare rock uncovered by organisms. In general, this fringe was characterized by a few encrusting lichens, small littorinid gastropods and cyanonobacteria, which might be considered as a worldwide feature of the upper zone in intertidal rocky shores (Little and Kitching, 1996; Boaden and Seed, 1985). This band was characterized by a higher coverage of grazing gastropods, Littorina spp, which were also found over a large extension in the Western Atlantic (Coelho et al., 2004). The ecological importance of these grazers is related to the control of microalgal populations (Apolinário et al., 1999). Aggregation, selection of habitat, decreasing shell pigmentation and increased/decreased shell ornamentation are some adaptations of Littorina to survive in this harsh environment where the desiccation stress is the highest (Chapman and Underwood, 1996). According to the scheme proposed by Lewis
(1964), the upper limit of the genus Littorina characterizes the boundary between the Supralittoral and the Littoral fringe. The species L. ziczac and L. flava were both recorded in the littoral fringe, although the latter occurred mainly in shaded places such as cracks and rocky fissures (personal observation).

Increasing environmental stress has historically been related to lower diversity, richness and higher species dominance (Clarke and Warrick, 2001). The sharp reduction of the above numerical descriptors on the uppermost height of the studied breakwater indicated a highly stressed environment, where the physical factors such as heat and desiccation were more severe due to the longer exposure time. However, tide oscillations at the intermediate levels of the substrate turned the environment into a less stressful one and allowed several organisms to inhabit this zone.

The Upper and Lower Eulittoral zone (1.6-0.8 m) presented a variety of algae and invertebrate species. This zone extended from the extreme high water spring tide (EHWST) to the mean tide level (MTL). The extension of this zone was marked mainly by Chthamalus spp. Others organisms such as mussels, polychaetes and algae were present as patches, which form a mosaic pattern mainly in lower level of this zone.

The high variability in the relative abundance of the dominant species among the profiles in the Eulittoral zone should be emphasized. The 
horizontal variability in the benthic organisms' distribution might be attributed to the high topographic irregularity of the rocky substrate, which reflected in different wave action intensity at the same height, favoring the establishment of different species. On the rocky shores of Cabo Frio (southeastern of the state of Rio de Janeiro), there was a considerable heterogeneity in the canopy structure, resulting on distinct patches of organisms (Yoneshingue, 1985 apud Machado et al., 1992).

The division of the eulittoral zone is commonly observed (Gevertz, 1995; Coutinho, 2002). In the present study, it was divided into two sub zones: Upper eulittoral zone (1.6-1.2m) and lower eulittoral zone (1.2-0.8m).

The Upper Eulittoral zone was mainly characterized by the cirripeds Chthamalus bisinuatus and $C$. proteus, commonly found on Brazilian rocky shores. According to Coelho et al. (2004), the distribution of these species on Brazil is from Rio Grande do Norte to Santa Catarina. In this sub zone, aridity caused by exposure to air was still intense, but a reduction of the empty space in the area was observed. The grazer $L$. ziczac appeared amongst the cirripedes but not as abundant as on the littoral fringe, which was usually called "Littorinid zone". However, Apolinário et al. (1999) observed that littorinids were much more abundant in the middle-intertidal zone aggregating amongst cirripedes. The grazing limpet Collisella subrugosa, commonly found in this zone, was also mentioned as an abundant archiogastropod in the Brazilian coast, occurring from the tropical northeast up to the subtropical southeast coast (Rios, 1995 apud Tanaka, 2001). Another mollusk, Brachidontes solisianus though present along the eulittoral zone, showed a higher relative abundance on the upper sub zone.

The Lower Eulittoral zone extended from mean high water (MHW) to mean tide level (MTL). It revealed the highest species diversity and richness, showing an even distribution. A bare rock decreasing value to $<10 \%$ was evident. Three distinct patches forming a mosaic pattern could be observed in this sub zone: the first one with Chthamalus spp, C. subrugosa and B. solisianus; the second one formed by tufts of rhodophytes including C. clavulatum and G. griffithsiae and the third one with $P$. lapidosa and U. fasciata.

The Sub-Littoral Fringe ( 0.8 to $0.2 \mathrm{~m}$ ) ranged from the mean tide level (MTW) to the extreme low water spring (ELWS), which corresponded to the lowest tide level. It represented a transition band to the Sublittoral zone, where the emersion time was the lowest of the intertidal region. Irregular patches of the mussel Perna perna occuped this zone, and its existence was more related to wave exposure areas (personal observation). The sandy reefs of the polychaete Phragmatopoma lapidosa were the local substrate for several species in this area. In southeastern Brazil, this species builds extensive sandy reefs through a set of compacted individual tubes, where the organisms settle themselves (Amaral, 1987 apud Micheletti-Flores, 1999). It was common to observe a changing color from green or red, due to the dominance of the chlorophyte $U$. fasciata or the rhodophyte $C$. clavulatum to brownish, due to the sandy reefs of P. lapidosa. In the lowest level of the sub-littoral fringe, the rhodophyte Hypnea musciformis was the characteristic species. This macroalgae is also abundant in the inferior part of the intertidal zone of Rio de Janeiro coast at Cabo Frio (Coutinho, 2002), Búzios (Machado et al., 1992) and Ilha Grande Bay (Brito et al., 2002), and in the extreme north (Oliveira et al., 1984) and south (Gevertz, 1995) of the State of São Paulo.

The distribution patterns of organisms on the intertidal breakwater on north coast of the State of Rio de Janeiro presented characteristics of other Brazilian natural rocky shores. Horizontal changes of species distributions over very small spatial scales of the shore formed a mosaic of organisms mainly in the middle shore, due to the substrate irregularity and discontinuity. The information obtained in the present study after the implantation of a breakwater on an area without natural rocky shores filled in a gap referring to the benthic community and its vertical distribution on intertidal rocky substrate on the north coast of Rio de Janeiro, and provided an observation basis for current and future experimental work.

\section{ACKNOWLEDGEMENT}

We thanks CNPq - Conselho Nacional de Desenvolvimento Científico e Tecnológico (Processes N ${ }^{\mathrm{o}} 301345 / 2004-0$; $\mathrm{N}^{\mathrm{o}} 301345 / 2004-0$ ) and FAPERJ - Fundação de Amparo à Pesquisa do Estado do Rio de Janeiro (Process $\mathrm{N}^{\circ}$ E26/170.260/2005) for grants and scholarship. 


\section{RESUMO}

O presente estudo teve como objetivo apresentar um esquema de zonação vertical de organismos bênticos da região entremarés em blocos graníticos na praia do Farol de São Tomé $\left(22^{\circ} 02 ' S, 41^{\circ} 03^{\prime} \mathrm{W}\right)$ na costa norte do estado do Rio de Janeiro. Quadrados de $20 \times 20 \mathrm{~cm}$ foram sobrepostos em quatro perfis e utilizado o método por foto quadrat com 100 pontos de interseção. A análise de agrupamento e a porcentagem de cobertura de organismos bênticos indicadores sugeriram um padrão na distribuição vertical da região entremarés com quatro faixas: Franja do Supralittoral caracterizado por espaço vazio e Littorina ziczac; Médiolitoral Superior ocupado por Chthamalus spp e espaço vazio; médiolitoral inferior caracterizado por Chthamalus spp, Phragmatopoma lapidosa, Ulva fasciata e Centroceras clavulatum; e Franja do Infralitoral caracterizado por $U$. fasciata, $P$. lapidosa e Hypnea musciformis. A alta variabilidade na abundância relativa das espécies dominantes entre os perfis na zona Médiolitoral é atribuída a alta irregularidade topográfica do substrato, refletindo em diferentes intensidades de exposição às ondas em uma mesma altura, o que favorece o estabelecimento de diferentes espécies. A alternância freqüente do tipo de substrato de rocha granítica para recifes arenosos de P. lapidosa pode ter contribuído para a variabilidade espacial em pequena escala. Este estudo preenche uma lacuna referente à comunidade bêntica e sua distribuição vertical no norte do estado do Rio de Janeiro. A adição do molhe em uma área caracterizada pela ausência de substrato consolidado natural possibilitou o estudo da zonação da comunidade bêntica entremarés, oferecendo uma base de dados para futuros trabalhos experimentais.

\section{REFERENCES}

Apolinário, M.; Coutinho, R. and Baeta-Neves, M. H. (1999), Periwinkle (Gastropoda: Littorinidae) habitat selection and its impact upon microalgal populations. Brazil. J. Biol, 59 (2), 211-218.

Araújo R.; Bárbara I.; Sousa-Pinto I. and Quintino V. (2005), Spatial variability of intertidal rocky shore assemblages in the northwest coast of Portugal. Estuar. Coast.Shelf Sci., 64, 658-670.
Archambault, P. and Bourget, E. (1996), Scales of coastal heterogeneity and benthic intertidal species richness, diversity and abundance. Mar. Ecol. Progr. Ser., 36, 111-121.

Benedetti-Cecchi, L. and Cinelli. F. (1997), Spatial distribution of algae and invertebrates in the rocky intertidal zone of the Strait of Magellan: are patterns general? Polar Biol., 18, 337-343.

Boaden, P. J. S. and Seed, R. (1985), An Introduction to Coastal Ecology. Blacckie and Son, Glasgow.

Boaventura, D.; Ré P., Fonseca, L. C. and Hawkins, S. J. (2002), intertidal rocky shore communities of the continental portuguese coast: analysis of distribution patterns. Mar. Ecol., 23 (1), 69-90.

Brattström, H. (1999), Description of the littoral zonation at nine Bahamian rocky-shore localities. Sarsia, 84, 319-365.

Brito L. V. R.; Széchy M. .T. M. and Cassano, V. (2002), Levantamento taxonômico das macroalgas da zona das marés de costões rochosos adjacentes ao terminal Marítimo Almirante Maximiano Fonseca, Baía da Ilha Grande, RJ. Atlântica, Rio Grande, 24 (1), 17-26.

Bulleri, F. and Chapman, M. G. (2004), Intertidal assemblages on artificial and natural habitats in marinas on the north-west coast of Italy. Mar. Biol., 145, 381-391.

Bulleri, F. (2005), Experimental evaluation of early patterns of colonisation of space on rocky shores and seawalls. Mar. Environ. Res., 60, 355-374.

Bulleri, F.; Menconi, M.; Cinelli, F. and BenedettiCecchi, L. (2000), Grazing by two species of limpets on artificial reefs in the northwest Mediterranean. $J$. Exp. Mar. Biol. Ecol., 255, 1-19.

Chapman, M. G. and Bulleri, F. (2003), Intertidal seawalls: new features of landscape in intertidal environments. Landsc. Urban Plan., 62, 159-172.

Chapman, M. G., and Underwood, A. J. (1996), Influences of tidal conditions, temperature and desiccation on patterns of aggregation of the highshore periwinkle, Littorina unifasciata, in New South Wales, Australia. J. Exp. Mar. Biol. Ecol., 196, 213237.

Coelho, P. A.; Tenório, D. De O.; Ramosporto, M. M. and Rosa, De L. S. (2004), A fauna bêntica do Estado de Pernambuco. In-Oceanografia: Um Cenário Tropical, eds E. Eskinazi-Leça; S. Neumann-Leitão and M. F. Costa. Edições Bagaço, Recife, pp. 477527.

Connel, J. H. (1961), The influence of interspecific competition and other factors on the distribution of the barnacle Chthamalus stellatus. Ecology, 42, 710723.

Coutinho, R. (1995), Avaliação crítica das causas da zonação dos organismos bentônicos em costões rochosos. Oecol. Brasil., 1, 259-271. 
Coutinho, R. (2002), Bentos de Costões Rochosos. InBiologia Marinha, eds R. C. Pereira and A. SoaresGomes. Interciência Press, Rio de Janeiro, pp.147157.

Cusson M. and Bourget, E. (1997), Influence of topographic heterogeneity and spatial scales on the structure of the neighbouring intertidal endobenthic macrofaunal community. Mar. Ecol. Progr. Ser., 150, 181-193.

Denny, M. W. and Paine, R. T. (1998), Celestial mechanisms, sea-level changes, and intertidal ecology. Biol. Bull., 194, 108-115.

Forde, S. and Raimondi, P. T. (2004), An experimental test of the effects of variation in recruitment intensity on Intertidal community composition. J. Exp. Mar. Biol. Ecol., 301, 1-14.

Gevertz, R. (1995), Em Busca do Conhecimento Ecológico: Uma Introdução a Metodologia. Edgard Blucher, São Paulo.

Good, T. P. (2004), Distribution and abundance patterns in caribbean rocky intertidal zones. Bull. Mar. Sci., 74 (2), 459-468.

Guichard, F.; Bourget, E. and Robert, J. L. (2001), Scaling the influence of topographic heterogeneity on a intertidal benthic communities: alternate trajectories mediated by hidrodinamics and shading. Mar. Ecol. Progr. Ser., 217, 27-41.

Guichard, F. and Bourget, E. (1998), Topographic heterogeneity, hydrodynamics, and benthic community structure: a scale-dependent cascade. Mar. Ecol. Progr. Ser., 171, 59-70.

Kohler, K. E. and Gill, S. M. (2006), Coral point count with excel extensions (CPCe): a visual basic program for the determination of coral and substrate coverage using random point count methodology. Comput. Geosci., 32 (9), 1259-1269.

Lewis, J. R. (1964), The Ecology of Rocky Shore. English University Press, London.

Little, C. and Kiching, J. A. (1996), The Biology of Rocky Shores. Oxford University Press, Oxford.

Machado, K. S. S.; Chapman, A. R. O. and Coutinho, R. (1992), Patch structure in a tropical rocky shore community in Brazil: a mosaic of successional states? Ophelia, 35 (3), 187-195.

Micheletti-Flores, C. V. and Negreiros-Fransozo, M. L. (1999), Porcellanid crabs (Crustacea, Decapoda) inhabiting sand reefs built by Phragmatopoma lapidosa (Polychaeta Sabellariidae) at Paranapuã beach , São Vicente, SP, Brazil. Brazil. J. Biol., 59 (1), 63-73.
Oliveira, E. C. and Paula, E. J. (1984), Aspectos da distribuição vertical e variação sazonal de comunidades da zona das marés em costões rochosos do litoral norte de São Paulo. Brazil. J. Biol, 147, 4471.

Preskitt, L. B. (2004), A rapid ecological assessment (REA) quantitative survey method for benthic Algae using photoquadrats with scuba. Pacific Sci., 58 (2), 201-209.

Sabino, C. M. and Villaça, R. (1999), Estudo comparativo de métodos de amostragem de comunidades de costão. Brazil. J. Biol, 59, 407-419.

Skinner, L. F. and Coutinho, R. (2005), Effect of microhabitat distribution and substrate roughness on barnacle Tetaraclita stalactifera (Lamarck, 1818) settlement. Braz. Archives Biol. Technol., 48 (1), 109113.

Souza W. P. (1979), Experimental investigations of disturbance and ecological succession in a rocky intertidal algal community. Ecol. Monogr., 49, 227254.

Stephenson, T. A. and Stephenson, A. (1949), The Universal feature of zonation between tide-marks on rocky coasts. J. Ecol,. 37, 289-305.

Tanaka, M. O.; Duque-Estrada, T. E. M. and Magalhães, C. A. (2001), Dynamics of the Acmaeid limpet Collisella subrugosa and vertical distribution of size and abundance along a wave exposure gradient. J. Molluscan Stud., 68, 55-64.

Thomas, M. L. H., (1985), Littoral community and zonation on the rocky shores of Bermuda. Bull. Mar. Sci., 37, 857-870.

Tomanek, L. and Helmuth, B. (2002), Physiological ecology of rocky intertidal organisms: a synergy of concepts. Integr. Compar. Biol. 42, 771-775.

Underwood, A. J. (1981), Structure of a rocky intertidal community in New South Wales: Patterns of vertical distribution and seasonal changes. J. Exp. Mar. Biol. Ecol., 51 (7), 57-85.

Zacharias, M. A. and Roff, J. C. (2001), Explanations of patterns of intertidal diversity at regional scales. $J$. Biogeogr., 28, 471-483.

Zar, J. H. (1984), Biostatistical Analysis. Prentice Hall, New Jersey.

Received: November 20, 2006; Revised:April 12, 2007; Accepted: August 18, 2008. 